\title{
Ecology of the Ant Pogonomyrmex mayri: Distribution, Abundance, Nest Structure, and Diet
}

\author{
Charles Kugler \\ Department of Biology, Radford University, Radford, Virginia 24142, U.S.A. \\ and \\ María del Carmen Hincapié \\ Calle 55 No. 38-30, Medellín, Colombia
}

\begin{abstract}
Although the North American seed harvesting ants of the genus Pogonomyrmex have been studied for many years, this is the first report of the ecology of a South American species. The entire distribution of $P$. mayri seems limited to desert or very dry forest in northeast Colombia. Colonies are of moderate size for the genus, averaging 603 workers per nest. Nest density, however, is high, resulting in a biomass comparable to that of Pogonomyrmex with much larger colonies. Nests have hidden entrances and consist of only two levels and a few chambers. Nest relocation in the area studied was frequent and executed within four or five hours. Unlike most Pogonomyrmex so far studied, P. mayri is not granivorous, but rather relies mostly on dead arthropods for food
\end{abstract}

ANTS OF THE GENUS Pogonomyrmex are distributed throughout the western hemisphere from Patagonia to southern Canada (Kusnezov 1951). They are one of the most primitive genera of the extremely successful subfamily Myrmicinae. In order to understand this subfamily, its origins, and its radiation, it is important to study the biology of its more primitive members.

Because of their large size, conspicuous nests, and remarkable habit of gathering and storing seeds, a few North American species of the subgenus Pogonomyrmex have received a great deal of attention for many years (see Wheeler 1910, Cole 1968, MacKay 1981 for references). Their obligate granivory, however, is almost certainly derived and unrepresentative of myrmicine ancestry. Within the genus are many species with apparently much less developed granivory (Creighton 1952, 1956; Kusnezov 1959; MacKay 1981), but their habits are little known, particularly those of the South American species.

This, in fact, is the first ecological study of any South American Pogonomyrmex. Pogonomyrmex mayri is the sole member of the subgenus Forelomyrmex, which is morphologically most related to the less conspicuous members of the subgenus Ephebomyrmex (Kugler 1978b). Here we present observations on distribution, abundance, nest characteristics, and diet of Pogonomymex mayri. Elsewhere we will examine its foraging and territorial behavior $(\mathrm{Ku}-$ gler, in prep.).

\section{MATERIALS AND METHODS}

Most observations other than distributional data are from a site about eight $\mathrm{km}$ east of Santa Marta, Colombia in Tayrona National Park (Parque Nacional Tayrona). The main study area was a $33 \mathrm{~m} \times 40 \mathrm{~m}$ plot in the forest behind the beach at Gairaca Bay. In that plot we laid out a $3 \mathrm{~m} \times 3 \mathrm{~m}$ grid of numbered stakes and mapped important landmarks so that the position of nests and ants could be located to the nearest half meter. In some cases it was necessary to make a finer grid of one $\mathrm{m}^{2}$. Most data were collected between September 1977 and April 1978.

Nests were located by baiting foragers with bits of roasted peanuts and were marked by a small flag of colored tape. Eight nests were excavated to determine colony size, and three of those were measured and sketched in the process. Working in pairs, we dug slowly and methodically in order to make accurate drawings and to collect all workers and brood in aspirators. We dug about $20 \mathrm{~cm}$ after finding no more ants, then returned at intervals to collect any returning foragers and check for new emergences. Ants were cleaned of dirt, frozen, sorted, and dried prior to weighing.

Nest density was determined by actual count in our mapped study area in the Gairaca alluvial plain, and estimated by the point quarter method (Grieg-Smith 1964) in the forest behind Neguange Bay, an adjacent bay to the east. In Neguange, one transect of five points ran through the flat, sea-level alluvial plain, and another of four points followed the $100 \mathrm{~m}$ elevation line. These data, along with colony size and dry weights, were used to calculate biomass. In the Neguange alluvial plain transect, we recorded distance to nearest neighbors and calculated the dispersion index according to Clark and Evans (1954).

Early in the study we noted that $P$. mayri colonies in our study area changed nests frequently. We recorded nest 


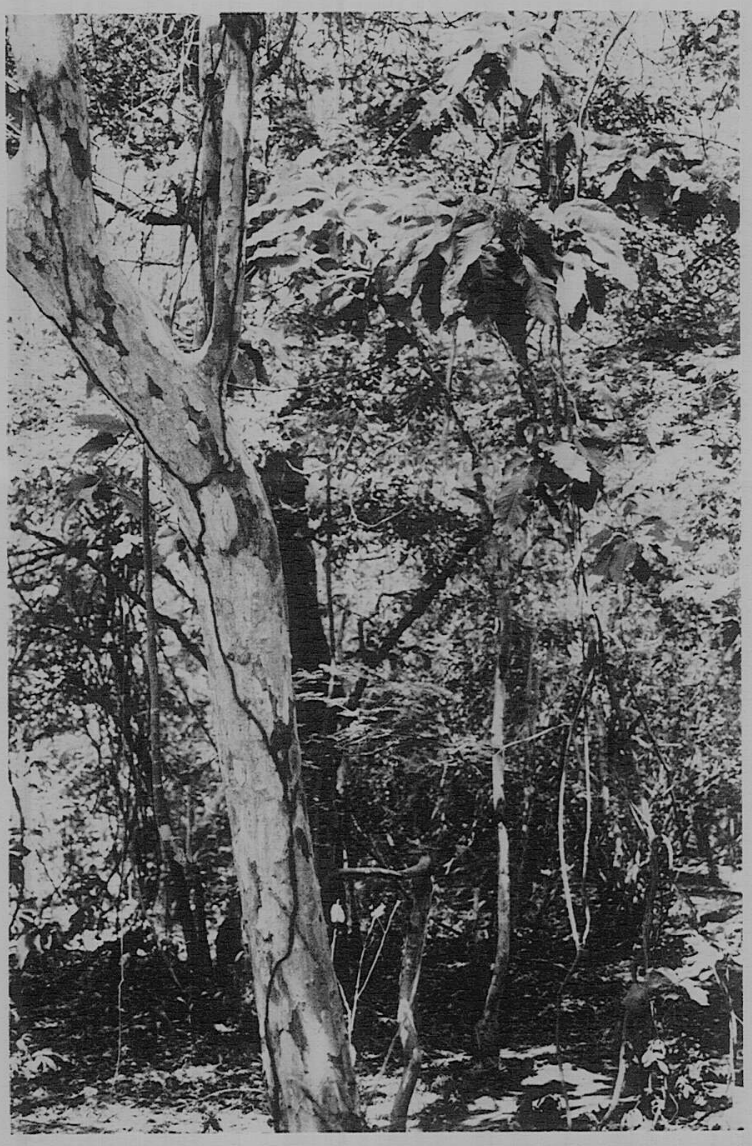

FIGURE 1. Understory vegetation near study site at Gairaca Bay in Tayrona National Park.

changes during the rainy season (3 Nov-15 Dec 1977) and the dry season (19 Mar-18 April 1978) for the 15 colonies in our study site and for 15 control colonies in an equivalent area about $100 \mathrm{~m}$ away. The study site ants were being disturbed by diet and foraging experiments; the control colonies, except for the occasional baiting of a worker to find a relocated nest, were unexposed to our activities. Both areas, however, were exposed to movements of cattle from a nearby ranch, the effect of which we did not test. Both sites were monitored every five to ten days. In the study site we recorded how many colonies had moved and plotted their locations on a map. The control nests were not mapped, but the distance moved was estimated.

The diet of $P$. mayri was studied in a way that would yield an estimate of the quantities of different food types taken. During several rainy months (September-November 1979) and several dry months (March-April 1980) we sampled the diet of ants in our study site by aspirating all foragers returning to their nests with something in their mandibles. During the rainy season we sampled a different nest each hour for the full 12 hours of their daily activity. At the end of each hour the forage was collected into a vial, and the ants were released at their nest entrance. Working in alternating hourly shifts, we could get continuous collections so that each 12 hour sampling period represented the daily intake of a composite average nest. In the laboratory the day's collection was sorted, and the numbers of different food types were counted. Anything carried by a single ant was counted as a single item, including parts of insects or flowers. Ants, isopods, termites, and seeds were usually entire. Items were then grouped according to whether they were of plant or animal origin, dried, and weighed. During the dry season the senior author worked alone, so nests were sampled only every other hour and the dry weight of the six hours' worth of material was doubled to get a 12 hour estimate comparable to that of the rainy season. In addition to these quantitative studies, we also tried baiting the ants with a variety of foods and observed their foraging habits.

The Chi square test at $P=.05$ was used throughout for tests of significance. Elevations, unless otherwise cited were taken with a pocket altimeter calibrated at known altitudes.

\section{RESULTS}

GeOgRaPhic Distribution AND habitat.-Pogonomyrmex mayri is a common and conspicuous ant in the environs of Santa Marta and the western half of Tayrona Park. During the day one often sees scattered individuals of this fairly large $(8-9 \mathrm{~mm})$ velvety-black ant walking slowly across the bare desert soil.

The rainfall in the Santa Marta area is $20-50 \mathrm{~cm}$ per year, with nearly all of the rain falling between September and December. Some years there is an additional, brief, rainy season, the "inviernito," in April.

Vegetation in areas exposed to the desiccating sea breezes is classified as "tropical thorn forest" in the Holdridge system (Espinal and Montenegro 1963). It is dominated by the cacti Cereus margaritensis and Peireskia guamacho, and the mimosaceous trees Prosopis juliflora and Acacia tortuosa. More protected areas, such as the study site at Gairaca, have "very dry tropical forest" dominated by larger deciduous trees reaching a height of 15-20 m, but rarely producing a covered canopy. Common trees of this habitat are Enterolobium cyclocarpum, Astronium graveolens, Bursera simaruba, Hura crepitans, Sterculia sp. Triplaris americana, and Pseudobombax septenatum. The understory in this area consists of patchily distributed tangles of often thorny vines and shrubs (Fig. 1). Common species are Senegalia tamarindifolia, $M i$ mosa leiocarpa, Morisonia americana, Eritbroxylum cartagenense, Pitbecellobium dulce, Croton nivens, Jacquinia aristata, Bumelia sp., Plumeria sp., Guazuma sp., Paul- 


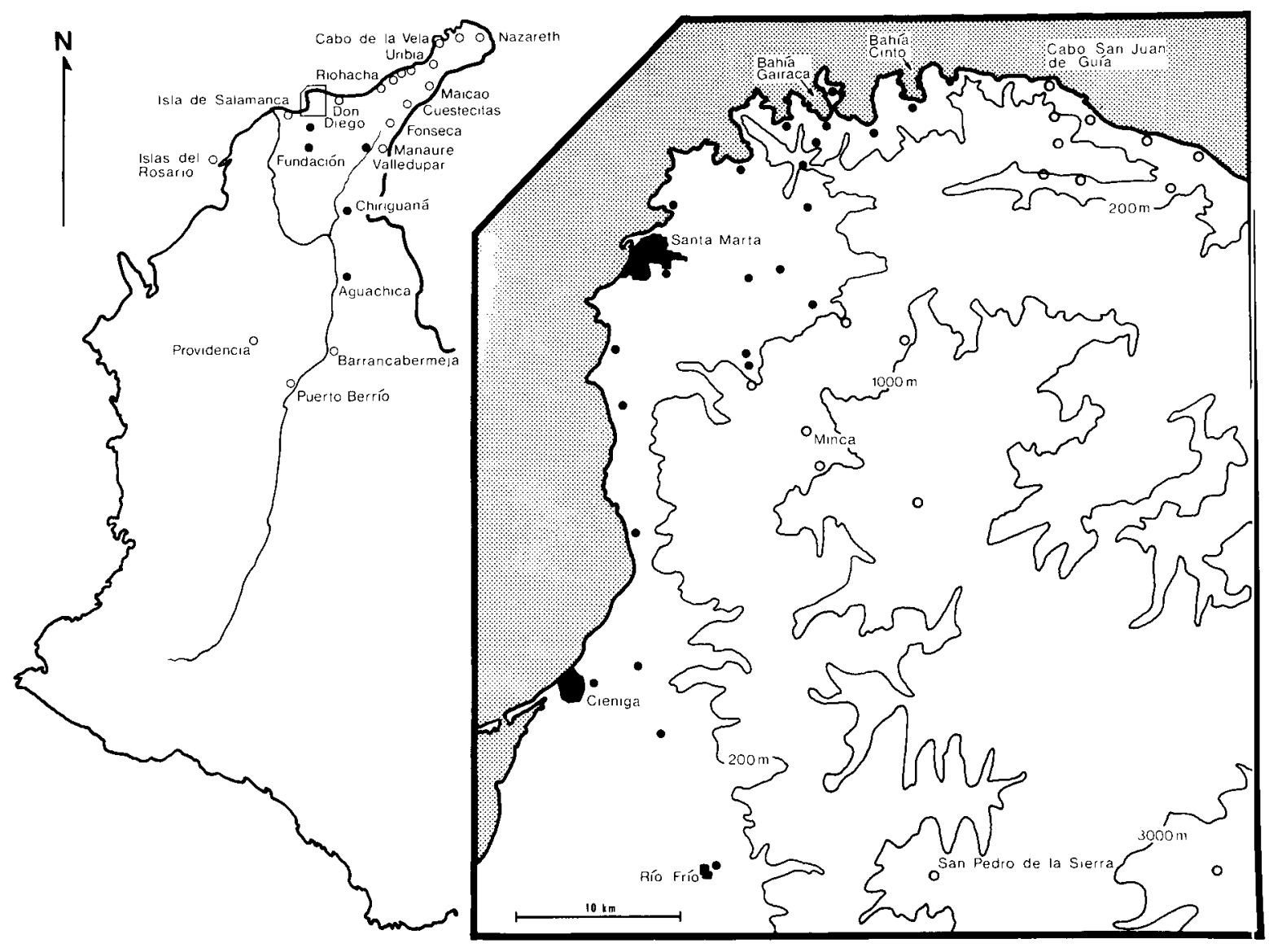

FIGURE 2. Distribution of Pogonomyrmex mayri. The solid circles show localities where $P$. mayri have been found; the open circles, where they have not been found by collectors mentioned in the text. The map on the left is the Andean half of Colombiat, showing the long Magdalena River and Cesar, its tributary in the northeast. The Sierra Nevada de Santa Marta, an isolated mountain massif with peaks rising to over $5600 \mathrm{~m}$ within $50 \mathrm{~km}$ of the north coast, is located in the area between Don Diego, Fundación, and Valledupar. The peaks of the Sierra de Perijá form the Colombia/Venezuela border north of Chiriguaná. Some reference elevations are: Maicao, $52 \mathrm{~m}$; Fonseca, about $200 \mathrm{~m}$; Valledupar, $168 \mathrm{~m}$; Fundación, $42 \mathrm{~m}$; Chiriguaná, $72 \mathrm{~m}$; Aguachicit, $162 \mathrm{~m}$; Barrancabermeja, 111-121 m; Puerto Berrio, $123 \mathrm{~m}$; and Providencia, $520 \mathrm{~m}$. Others are at less than $100 \mathrm{~m}$ (Arenás Paz 1939, Instituto Geográfico Agustin Codazzi 1970, pers. obs.). Many sites south and west of these have been collected by CK and other collectors with no records of $P$. mayri. The small box in this map is enlarged at right. Bahia Gairaca and Bahía Cinto are translated Gairaca Bay and Cinto Bay in the text. Neguange Bay is between them.

linia sp., Bactris sp., and three Capparis spp. (Gerhard Heybrock, personal communication).

In all directions from Santa Marta, the $P$. mayri distribution ends as rainfall increases (Fig. 2). Eastward, nests are common as far as Cinto Bay in about the middle of Tayrona Park but are entirely absent at Cabo San Juan de Guia eight $\mathrm{km}$ beyond. This is a typical distribution for insects of the area. In fact, during a two-year survey of the insects of the park, Kugler (unpublished) found only a 22 percent overlap (Coefficient of Community) in ant species of the east and west ends. The apparent reason for the species changeover is that the east end of the park receives about ten times as much rainfall as the west end.
The forest, though still classified as "very dry tropical forest" forms a higher canopy that is closed more of the year, and the understory is more stratified. Thus, the microclimate on the ground is more mesic. Farther east along the coast, rainfall decreases again so that by Riohacha vegetation is much as in Santa Marta, and on the Guajiran Peninsula it is even drier. Curiously, no P. mayri have been found in the Department of the Guajira even though Forel (1912), W. P. MacKay (pers. comm.), W. L. Brown (pers. comm.), and the senior author have collected there (Fig. 2).

To the southeast of Santa Marta is the Sierra Nevadiı de Santa Marta. With increasing elevation, the vegetation 
TABLE 1. Size of Pogonomyrmex mayri colonies as determined by excavation.

\begin{tabular}{lrrrrrr}
\hline $\begin{array}{c}\text { Date } \\
\text { of } \\
\text { excava- } \\
\text { tion }\end{array}$ & $\begin{array}{c}\text { Work- } \\
\text { ers }\end{array}$ & $\begin{array}{c}\text { Lar- } \\
\text { vae }\end{array}$ & Pupae & Males & Queens & Total \\
\hline $\begin{array}{l}\text { Oct. 77 } \\
\text { Mar. 78 }\end{array}$ & 685 & 151 & 120 & 12 & 0 & 968 \\
Apr. 78 & 481 & 15 & 10 & 1 & 1 & 508 \\
Apr. 78 & 410 & 26 & 12 & 0 & 0 & 448 \\
Apr. 78 & 203 & 35 & 46 & 0 & 0 & 284 \\
Apr. 78 & 701 & 107 & 163 & 28 & 0 & 999 \\
Apr. 78 & 792 & 87 & 111 & 21 & 1 & 1012 \\
May 78 & 881 & 33 & 3 & 9 & 0 & 926 \\
\hline
\end{tabular}

becomes more mesic and $P$. mayri sightings stop abruptly at about $200 \mathrm{~m}$ (Fig. 2). At lower elevations $P$. mayri's range extends south in dry scrub or scrubby forest along the Magdalena River valley to somewhere between Aguachica and Barrancabermeja; the range also follows the Cesar River valley northeast as far as Valledupar (W. P. MacKay collections, pers. comm.). Between Valledupar and Fonseca is a ridge $200-500 \mathrm{~m}$ in elevation that connects the Sierra Nevada de Santa Marta and the Sierra de Perijá. This may present a barrier that is not crossed by P. mayri.

The western extension of $P$. mayri's range has not been as well established. No $P$. mayri were seen in our few collections between Cieniga and Barranquilla, or during more extensive collecting on the Rosary Islands (Islas del Rosario) off the coast of Cartagena. Excluding $P$. mayri, these sites have an ant fauna very similar to Santa Marta's.

Nest structure, density, biomass, relocation.-Nests are most often located in soil at the bases of trees or shrubs, but occasionally in cracks at the bases of rocky out croppings, or high on a sandy beach. The entrance of a $P$. mayri nest is usually a large irregular opening 1-3 $\mathrm{cm}$ in diameter (Fig. 3). It is flush with the ground and unattended by a mound, crater, nest apron, or ring of vegetation. Instead, it is nearly always covered by dry leaves, a $\log$, or a stone. The three nests we drew as they were excavated from hard soil had sloping passageways from the surface about two $\mathrm{cm}$ in diameter and 30-40 $\mathrm{cm}$ long (Fig. 4). At a depth of about $10-20 \mathrm{~cm}$ each dilated into a horizontal chamber about five $\mathrm{cm}$ in height. In two nests, the chamber was cylindrical; in the other it was large and palmately lobed, the lobes being 3-9 cm in maximum width. From the floor of this upper chamber there were one or two vertical passages about $0.5 \mathrm{~cm}$ in diameter to another horizontal chamber or series of chambers. We did not find a third level in any nest. The total depths of the nests were 15,20 , and $22 \mathrm{~cm}$.
Each colony uses a single nest entrance at any one time, and members of adjacent nests are strongly territorial (Kugler, in prep.). Table 1 shows colony sizes. The average colony had 603 workers, 136 larvae and pupae, and 10 males. The brood counts from these excavations are surely somewhat low since small larvae are easily missed. Only two nests had females, each with a single ergatoid queen. No queens were seen developing in these nests, and none have ever been collected above ground. Males, in contrast, are common in nests, and possibly emerge year round from a population. We have specimens collected on vegetation during the day in March, April, June, September, October, and November.

Density of nests in the alluvial plains of Gairaca and Neguange were 116.6/ha and 142/ha, respectively; nest density on the slopes of Neguange at $100 \mathrm{~m}$ elevation was $55.3 / \mathrm{ha}$. The mean dry weight of workers was 4.6 $\mathrm{mg}$; of males, $3.5 \mathrm{mg}$; and of immatures, $1.8 \mathrm{mg}$. From these data and the average nest size of 749 total individuals per colony ( 603 workers), we calculate a standing crop biomass for $P$. mayri of $355 \mathrm{~g} / \mathrm{ha}(321 \mathrm{~g}$ of workers/ha) in Gairaca, $435 \mathrm{~g} / \mathrm{ha}$ (393 $\mathrm{g}$ of workers/ha) in the Neguange plain, and $169 \mathrm{~g} / \mathrm{ha}$ (153 g of workers/ ha) at $100 \mathrm{~m}$ in Neguange. The lower nest density and biomass at $100 \mathrm{~m}$ are consistent with our inability to find P. mayri above $200 \mathrm{~m}$ around Santa Marta.

With the dispersion measure of Clark and Evans (1954), aggregation is maximum at $R=0$, perfectly random at $R=1$, and uniformly spaced at $R=2.1491$. For $P$. mayri in the sea level plain of Neguange, $R=1.52$, which is significantly larger than 1 , and therefore indicates overdispersion.

Nest relocation was common, especially among those in our study site, where foragers of a majority of colonies were manipulated each week for dietary observations and other experiments. An average of 25.5 percent of the study site nests moved each week (Range 7-43\%) compared to 10 percent for the control nests (Range $0-53 \%$ ). Stated another way, the average study site colony moved every 23 days while the control colonies moved every 65 days. The difference is significant. These rates, though rather high, nevertheless underestimate the actual rates to some degree since we recorded nest sites weekly and surely missed some relocations. The frequency of nest moving was not significantly different between wet and dry seasons for either the control $(0.95<P<0.90)$ or studysite nests $(0.25<P<0.50)$. The average distance moved was $1.3 \mathrm{~m}$ for the study-site nests (Range $0.2-3.8 \mathrm{~m}$, SD $0.94 \mathrm{~m}, N=66$ ), and $1.5 \mathrm{~m}$ for the control nests (Range $0.3-5.0 \mathrm{~m}, \mathrm{SD} 1.18, N=14$ ). The difference is not significant $(0.1<P<0.25)$.

These data suggest that a fairly high rate of nest changing is normal for $P$. mayri in that area, and that even a mild form of disturbance may increase the rate of relocation. To test this hypothesis further, we tried to 


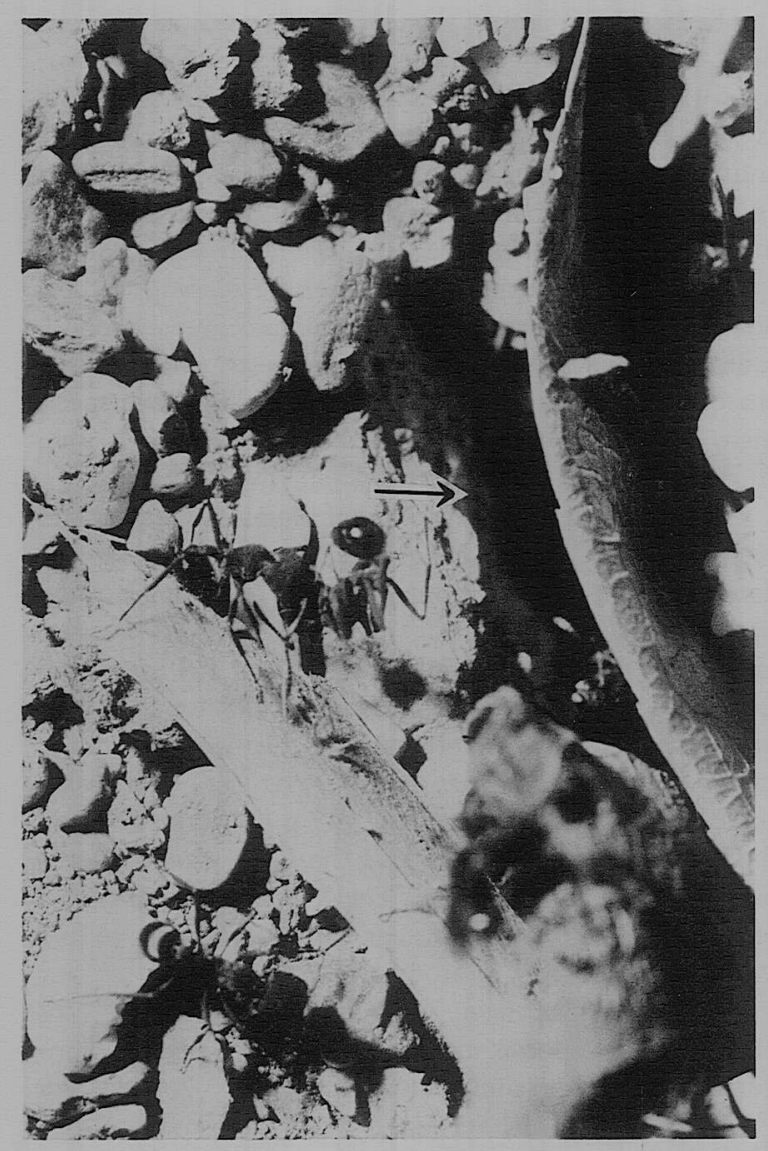

FIGURE 3. Entrance of a $P$. mayri nest in sandy soil (indicated by arrow). To the left of the entrance is one ant carrying another to the nest. The ant being carried is held upside down by the neck.

induce the relocation of two colonies. One colony was disturbed by shallow digging at the entrance and by thrusting a stick into it; the other colony was confined to its nest for a day by covering the entrance with a can. In both cases, emigration was in full swing by two to three hours after our activities.

Disturbance in the form of intraspecific competition also causes $P$. mayri colonies to relocate. On three occasions we witnessed extended fighting between foragers of different colonies in the region where their territories touched or overlapped. In each case, one of the colonies moved within several days so that their territories were no longer in contact.

We saw only one relocation attributable to interspecific competition. Odontomachus bauri is a much larger, more aggressive, predatory ant, which forages only at night for most of the year. Since $P$. mayri is strictly diurnal (Kugler, in prep.) it is exposed to 0. bauri only during

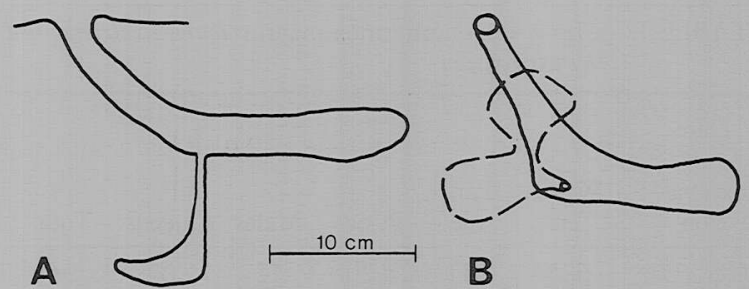

FIGURE 4. Typical nest of Pogonomyrmex mayri in soil. A. Side view. B. View from above. The dashed line is the lower chamber. This nest held 701 adult workers along with males and brood.

the rainy season when milder temperatures permit diurnal foraging by 0 . bauri. One day during the early part of the rainy season, we noticed foragers of one $P$. mayri colony repeatedly being pursued and attacked in one sector of their territory by 0 . bauri from a nearby nest. The next morning the $P$. mayri colony moved to an area where 0 . bauri were not foraging.

Another possible cause of nest relocation could be seasonal fluctuation in microclimate. Several areas in and adjacent to our study site were free of canopy and understory vegetation, and so for much of the year bare ground and leaf litter were exposed to direct sun. In the rainy season, however, a tall, dense herbaceous stratum formed. During November and December of the 1977 rainy season we noted that five colonies in our study area relocated into those dense weeds. By March of the next dry season all five had left the once again barren patches. Four had their new nest entrances in the shade near the bases of trees or shrubs; the fifth had moved from the study area and could not be located. It is possible that the colonies were forced out into the weedy area by greater competition during the rainy season, but returned to the shade in the dry season to escape the intense heat of direct sun on their nest entrances, which prevents foraging during midday (Kugler, in prep.).

When colonies relocate, they more often reoccupy vacant nests in or near their territories than dig new ones. Only twice did we observe what looked like excavation of new nests. Both occurred during the rainy season, and both were abandoned before completion. Nest digging may be rare because the soil is very hard except for the brief rainy season, making excavation difficult and permitting old unoccupied nests to remain intact. Of the 74 nest relocations noted, 24.3 percent were returns to the nest chamber last occupied by the colony. Others moved to a third or fourth nest before returning to the first. There were very few signs of reconstruction after a colony moved into a new nest.

Nest relocation is organized at least in part by foragers carrying nestmates to the new site by the neck in the 
typical myrmicine manner (Fig. 3) (Möglich and Hölldobler 1974). We never witnessed the initiation of a nest relocation, but we were able to study the final stages for four different colonies. At one nest, which we could not watch continuously because of involvement in other experiments, there was no activity at 5:30 A.M., but at 6:30 and 7:30 there were files of workers leading to the new nest entrance. None were carrying nestmates at those times, but by $8: 30$ they were transporting workers, males, and brood. From 8:40 to 9:05 the number of brood decreased from 10 per five minutes to zero, but the number of workers carried remained high at least until 9:20, fluctuating from 11 to 21 per five minutes; by 9:50 relocation had ceased. The same pattern was observed for the other three colonies. These observations suggest that relocation begins with recruitment of some workers, probably organized by the trail pheromone they possess (Kugler, in prep.). Then nest inhabitants are carried, with brood transport being completed before worker transport. Whether brood are transported at the beginning or in the middle of the process we do not know. In no relocation did we see a queen, any sign of colony fission, or tandem running.

We can assign only outside limits to the duration of nest moving. For each of the four cases, our observations show that the process could not have taken more than four or five hours.

The abundant geckos (Gonotodes sp.) served as a source of selection pressure for rapid relocation and early completion of brood transfer. On several occasions we witnessed one waiting by the trail of relocating ants, systematically ambushing those carrying brood. The gecko would grab the brood and shake off the ant. The slow, nonstinging $P$. mayri had no visible defense.

Diet.-Pogonomyrmex mayri could be characterized as a forest floor scavenger. It forages almost exclusively on the surface of the leaf litter or on bare soil, usually the latter. It rarely foraged inside the litter, and was never seen climbing more than $15 \mathrm{~cm}$ up a tree or shrub. It is a timid, slow-moving ant with small eyes. Even though it is endowed with a long, sharp, and rather well sclerotized sting (Kugler 1978b), it rarely, if ever, employed the sting for either offense or defense. We could never get workers to sting us. In territorial disputes with other colonies or with Ectatomma ruidum, they often balled up and flexed their gasters, but since their opponents always departed unharmed, the $P$. mayri probably did not sting effectively.

Pogonomymex mayri is extremely timid with live prey. Large insects that struggled were avoided. If we opened a mound of soldierless termites less than half the size of $P$. mayri, only dead ones were readily taken. The live ones were either avoided or taken after some hesitation. In such cases we only occasionally saw the gaster being flexed as if to sting, but the action seemed more for manipulation of prey. This behavior is in striking contrast to that of $P$. mayri's main competitor in the area, Ectatomma ruidum, which consistently grabbed and stung the first live termites they came across. The only prey we saw $P$. mayri take readily were very small insect larvae that could easily fit into the mandibles.

Foragers are highly attracted to peanuts and sweets, and defend such foods aggressively. In dealing with droplets of sugar or honey solution, they neither become physogastric nor carry droplets in their mandibles. Instead, they fill a drop of solution with rubble, then transport the coated twigs and gravel to their nests. Since $P$. mayri is exclusively a ground forager, and since we found no trace of root coccids in excavated nests, it does not normally come in contact with extrafloral nectaries or honeydew secreting insects. Sweets in other forms, however, do appear naturally on the ground. The common plants, Paullinia sp. and Capparis indica, drop seeds covered with a sweet pulp, and $P$. mayri strongly recruits to them.

Table 2 gives the percent composition of the diet of P. mayri in our Gairaca study site. Arthropods, mostly dead and dry, constitute the major fraction of $P$. mayri's diet, 72.5 percent in the wet season and 54.3 percent in the dry season. Termites and isopods are abundant in the rainy season and were taken in large numbers, but both were scarce during the dry season and are poorly represented in the diet during that time. Ants were more abundant in the rainy season, and relatively more abundant than other arthropods during the dry season. At that time they became a major component of the diet, especially dead workers of $E$. ruidum. Other arthropods taken repeatedly were dead thysanurans, live case bearers, and live fly larvae dug from cow manure.

Items of plant origin were taken the year around, but they constituted a much larger fraction of the forage during the dry season (42.7\%) than during the rainy season (20.0\%) (Table 2). Seeds were not a dominant food item in either season. Nearly all were dry and very small, and most belonged to three unidentified species. Occasionally, a larger pulpy seed was dragged to a nest, however, no seed caches were discovered during our nest excavations. In the dry season, flower parts, particularly the petals of one tree species (Lonchocarpus?), were taken to P. mayri nests in large numbers. Since they were often being removed at a similar rate, apparently unmasticated, we suspect that they were being licked for dried nectar, if used at all. MacKay (1981) notes similar behavior for other Pogonomyrmex, and suggests that it may serve to raise nest humidity. Fungi constituted only a minor part of the forage, and no evidence of fungus growing was seen in the nests.

We conclude from these studies that $P$. mayri is primarily a scavenger on arthropod remains, taking to a lesser degree very small, soft bodied, live arthropods, sweet 
substances, and some types of seeds. They neither tend insects or nectaries nor store seeds. They shift to a more herbivorous diet in the dry season when arthropods are scarce.

\section{DISCUSSION}

Pogonomyrmex mayri is geographically isolated from all other members of the genus. Species in the subgenus Pogonomyrmex are found in western North America from Mexico City into Canada with an additional species in southeastern United States. The subgenus Ephebomyrmex is found in southwestern United States, the Caribbean, and eastern South America from Venezuela and the Guianas to southern Argentina and Chile. The nearest neighbor of $P$. mayri is $P$. (E.) naegelii, which has been collected in Venezuela, but to our knowledge not in Colombia. Pogonomyrmex mayri's distribution seems confined to Colombia, to the thorn forest, and the very dry deciduous forest below $200 \mathrm{~m}$ around the western and southern skirts of the Sierra Nevada de Santa Marta. It is apparently cut off from the Guajiran Peninsula and Venezuela by the Sierra Nevada de Santa Marta and the mountain range that forms the Colombia/Venezuela border (Sierra de Perijá). Between the Sierra Nevada de Santa Marta and the coast directly north is a strip of somewhat more mesic lowland forest through which $P$. mayri could pass to thorn forest on the peninsula, but it does not. We believe there are two reasons why this forest presents an effective barrier. The first is greater competition from other ant species. In the region where $P$. mayri is abundant CK found 60 species of ants. Only one, Ectatomma ruid$u m$, was a common and effective competitor in our study area. In the more mesic forest where $P$. mayri is absent, there are some 134 species. Not only are there more potential competitors, but some competitors that are rare in the drier forest are more common. Since $P$. mayri has a slow recruitment system and an inefficient resource defense (Kugler, in prep.), it may not be able to survive competition in this more diverse ant community. The second reason for not colonizing the Guajira is provided by the wingless ergatoid queen of this species (Kugler $1978 \mathrm{~b}$ ); winglessness precludes mating flights and wind dispersal over the mesic barrier. A similar barrier may account for the end of the $P$. mayri range just north of Valledupar (Fig. 2). The western limits of $P$. mayri's distribution are still uncertain.

The North American species of Pogonomyrmex nest in deserts or grasslands from sea level to montane elevations, and usually in sites exposed to direct sun. Habitats are not well reported for the South American species, but some live in desert or altiplano like their North American congeners, others live in more mesic forests of Libocedrus or Notbofagus that receive up to $200-400 \mathrm{~cm}$ annual precipitation (Kusnezov 1949, 1951, 1959). Only $P$.

\begin{tabular}{|c|c|c|}
\hline & \multicolumn{2}{|c|}{ Percent of total items } \\
\hline $\begin{array}{l}\text { Items carried } \\
\text { to nests }\end{array}$ & $\begin{array}{l}\text { Rainy season } \\
\text { Sept.-Nov. } \\
(N=660)\end{array}$ & $\begin{array}{l}\text { Dry season } \\
\text { Mar.-April } \\
(N=384)\end{array}$ \\
\hline Termites & 25.8 & 3.1 \\
\hline Ants & 4.7 & 19.0 \\
\hline Other insects & 24.2 & 29.7 \\
\hline Arachnids & 2.3 & 1.5 \\
\hline Isopods & 15.5 & 1.0 \\
\hline Snails & 5.7 & 0.3 \\
\hline Seeds & 8.8 & 10.7 \\
\hline Flower parts & 5.3 & 28.6 \\
\hline Leaf fragments & 2.1 & 3.4 \\
\hline Fungal fragments & 3.8 & 0.0 \\
\hline Excrement & 1.7 & 2.9 \\
\hline Unidentified & 2.4 & 5.6 \\
\hline
\end{tabular}

(E.) odoratus is reported to nest in the shade of trees, and it does so rarely (Kusnezov 1949). The arid habitat of $P$. mayri is typical for the genus, but location of nests in the shade of trees seems unusual at present. Colonies of $P$. mayri are intermediate in size for the genus. The best known North American species may have from 1000 to over 12,000 workers per nest, but others have less than 100. South American species, as far as we know from scanty data, have a few hundred workers or less per nest (MacKay 1981). Pogonomyrmex mayri colonies containing about 200-900 workers are small compared with North American seed harvesters but may be average or large compared to other South American species.

Species with large colonies have more elaborate nest architecture. Members of the subgenus Pogonomyrmex, such as badius, barbatus, maricopa, rugosus, and occidentalis, usually have exposed nest entrances surrounded by a bare nest yard, mound, or crater and consist of columns of many chambers connected by narrow passageways to a depth of 1-4 m (Gentry and Stiritz 1972, Cole 1968, Lavigne 1969, Hölldobler 1976, MacKay 1981, and Whitford et al. 1976). Members of the subgenus Ephebomyrmex and some of the subgenus Pogonomyrmex have much smaller colonies, and mounds are small or absent (Creighton 1952, 1956, Cole 1968, Kusnezov 1959). Some Ephebomyrmex species have exposed nest entrances, but $P$. (E.) coarctatus, $P$. (E.) angustus, and $P$. (E.) odoratus hide entrances under leaves, rocks, or wood. Nests of $P$. (E.) imberbiculus and $P$. (E.) pima, which contain only about 50 workers, have entrances $3-4 \mathrm{~mm}$ in diameter from which three or four passageways extend less than $13 \mathrm{~cm}$ to a few small chambers (Creighton 1956). We see from this brief synopsis that $P$. mayri nests most resemble those of some Ephebomyrmex species by lacking 
craters or nest yards, having concealed nest entrances, and consisting of only a few chambers.

No density or biomass data is available for any South American Pogonomyrmex and for only six North American species (see MacKay 1981). These six species have colonies of more than 1900 workers per nest, densities of 131 nests / ha $\left(0.5-19.4\right.$ adult workers $\left./ \mathrm{m}^{2}\right)$ and dry weight biomass of $1.2-137.4 \mathrm{mg}$ of workers $/ \mathrm{m}^{2}$. Although $P$. mayri colonies are much smaller, the much higher nest density of 55-142 nests/ha results in a comparable density and biomass of ants (3.3-8.6 workers $/ \mathrm{m}^{2}$ and $15.3-$ $\left.39.3 \mathrm{mg} / \mathrm{m}^{2}\right)$. Regular dispersion of nests is typical for Pogonomyrmex and for ants in general (Levings and Traniello 1981).

Nest relocation has been most studied in $P$. badius (Golley and Gentry 1964, Gentry and Stiritz 1972, Gentry 1974). Gentry (1974) shows that over four years each colony moved an average of 1.4 times per year, with no significant difference between control nests and those treated to artificial predation. The mean distance moved was $4.4 \mathrm{~m}$ for the control colonies and significantly less, $2.5 \mathrm{~m}$, for the colonies subjected to the most predation. Only about six percent of the $P$. californicus colonies studied by DeVita (1979) moved each year, and they moved an average distance of $4.3 \mathrm{~m}$. These figures are much lower than the average of 5.6 moves per nest per year estimated for the $P$. mayri control group and 15.9 / yr for the disturbed group. From our observations it looks like disturbance, either directly to the nest or to foragers, increases the likelihood of nest relocation, but we do not know why the undisturbed control colonies should change nests four times as often as $P$. badius colonies and so frequently expose their brood to predation. Possible factors are the disturbance created by cattle in the area, the effects of a much smaller colony size, and the effects of dramatic biannual changes in vegetation and ant community structure. The smaller average distance moved by $P$. mayri as compared to $P$. badius and $P$. californicus is probably a straightforward function of their smaller territories (Kugler, in prep.).

A P. badius colony takes 10-14 days to relocate (Gentry and Stiritz 1972, Van Pelt 1976) and P. barbatus takes 6-25 days (Hölldobler 1976, Van Pelt 1976). Relocation is much faster for $P$. mayri ( $\leq 5$ hours), probably because of smaller colony size, lack of seed stores, and lack of need to excavate a new nest.

Worker transport by $P$. mayri during relocation is the most common form for myrmicines. Neck grasping is also used by $P$. maricopa, but $P$. badius, $P$. barbatus, and $P$. rugosus, use the more primitive method of simply lifting the nestmate by any part of the body (Möglich and Hölldobler 1974). Our limited observations suggest that relocation in P. mayri may be organized in the same manner as those of most Leptotborax species studied by Möglich (1978). Unlike Möglich, we saw no tandem running re- cruitment, but since we did not witness the initial steps of emigration, we missed the stage during which tandem running is most likely to be employed.

The best studied Pogonomyrmex are obligate seed foragers that harvest and store large quantities of seeds, grasses, and forbs, which constitute the major portion of their diet: $P$. (P.) occidentalis, 39-89 percent; $P$. (P.) rugosus, 68-98 percent; $P$. (P.) barbatus, 65-95 percent; $P$. $(P$.) californicus, 95-100 percent $P$. (P.) desertorum, 90-100 percent and $P$. (P.) subnitidus 62 percent (Rogers 1974, Whitford et al. 1976, Whitford 1978, MacKay 1981). Pogonomyrmex (P.) montanus does not store seeds, but seeds still make up about 32 percent of its forage (MacKay 1981). Less quantitative studies on members of the subgenus Ephebomyrmex indicate that those species are even less dependent on seeds. Seeds are thought to be a small part of the $P$. (E.) buachucanus diet, and even though $P$. (E.) pima and $P$. (E.) imberbiculus store seeds, lab colonies of the latter did not eat seeds until starved of insects (Creighton 1952, 1956; Cole 1968). The present study shows that $P$. mayri, unlike its well studied North American relatives, is not an obligate seed harvester, but rather, subsists mostly by scavenging dead arthropods and a variety of plant parts. This general diet, which may be common within Ephebomyrmex, is believed to be a primitive characteristic of the genus (Creighton 1952).

In summary, Pogonomyrmex mayri is very different from the better known members of the genus, which are seed specialists. Its colonies are smaller and more densely packed; nests are less exposed, shallower, and are vacated more frequently; queens are ergatoid and rare; workers do not sting; and the diet is more generalized. Many of these characteristics are probably primitive ones for the genus and perhaps for the subfamily Myrmicinae. From such a life one can envision how some species could come to specialize on the seed part of the diet, which in turn could require increased colony size, aggressiveness, and stinging ability in order to protect seed stores from rodents (Hermann 1971, Kugler 1978a: 433, W. L. Brown, pers. comm.). Larger colonies would in turn require larger territories and a lower nest density. This hypothesis could be tested with more information on the ecology of the less conspicuous Pogonomyrmex species, particularly those of the subgenus Epbebomyrmex. Studies of these primitive myrmicines should also contribute to our understanding of the origins and radiation of the subfamily Myrmicinae.

\section{ACKNOWLEDGMENTS}

Our sincerest thanks go to the Instituto de Investigaciones Marinas de Punta de Betín (INVEMAR). The generous cooperation of its directors, Gabriel Roldán, Bernd Werding, Friedmann Köster and Hernando Sanchez, and staff made the work possible. We also thank INDERENA for permission to work in Parque Tayrona Nacional. Gerhard Heybrock very kindly sup- 
plied identifications of plants, and William P. Mackay provided valuable unpublished collection data. This work was supported by the Peace Corps Smithsonian Program, COLCIENCIAS gran: No. 30003-1-02-77 and NSF grant No. DEB-8022177.

\section{LITERATURE CITED}

Arenas Paz, B. 1939. Guía geográfica de Colombia. Editorial Santa Fe, Bogotá, Colombia. 489 pp.

Clark, P. J., AND F. C. Evans. 1954. Distance to nearest neighbor as a measure of spatial relationships in populations. Ecology 35(4): $445-453$.

Cole, A. C. 1968. Pogonomyrmex harvester ants, a study of the genus in North America. The University of Tennessee Press: Knoxville. 222 pp.

CReighton, W. S. 1952. Studies on Arizona ants (3). The habits of Pogonomyrmex buachucanus Wheeler and a description of the sexual castes. Psyche 59: 71-81.

- 1956. Studies on the North American representatives of Ephebomyrmex (Hymenoptera: Formicidae). Psyche 63: 5466.

DE VITA, J. 1979. Mechanisms of interference and foraging among colonies of the harvester ant Pogonomyrmex californicus in the Mojave Desert. Ecology 60(4): 729-737.

Espinal, L. S., and E. Montenegro. 1963. Formaciones vegetales de Colombia. Instituto Geográfico Agustin Codazzi, Bogotá. $201 \mathrm{pP}$.

Forel, A. 1912. Formicides néotropiques. Part IV. Sous-famille Myrmicinae (suite). Mém. Soc. R. Belg. Entomol. 20 : 1-32.

Gentry, J. B. 1974. Response to predation by colonies of the Florida harvester ant, Pogonomyrmex badius. Ecology 55: 13281338.

- AND K. L. StiRitz. 1972. The role of the Florida harvester ant, Pogonomyrmex badius, in old field mineral nutrient relationships. Environ. Entomol. 1(1): 39-41.

Golley, F. B., AND J. B. Gentry. 1964. Bioenergetics of the southern harvester ant, Pogonomyrmex badius. Ecology 45(2): $217-$ 225.

Grieg-Smith, P. 1964. Quantitative plant ecology, 2nd ed. Butterworth Ltd., Publ., London. 256 pp.

Hermann, H. R. 1971. Sting autotomy, a defensive mechanism in certain social Hymenoptera. Insectes Soc. 18: 111-120.

Hölldobler, B. 1976. Recruitment behavior, home range orientation and territoriality in harvester ants, Pogonomyrmex. Behav. Ecol. Sociobiol. 1: 3-44.

Instituto Geográfico Agustin Codazzi. 1970. Atlas básico de Colombia. El Instituto. Bogotá, Colombia. 106 pp.

Kugler, C. 1978a. A comparative study of the myrmicine sting apparatus (Hymenoptera, Formicidae). Studia Entomol. 20: 413-548.

1978b. Description of the ergatoid queen of Pogonomyrmex mayri with notes on the worker and maie (Hym., Formicidae). Psyche 85: 169-182.

Kusnezov, N. 1949. Pogonomyrmex del grupo Ephebomyrmex en la fauna de la Patagonia. Acta Zool. Lilloana. 8: $291-307$.

-1951. El genero Pogonomyrmex Mayr (Hym. Formicidae). Acta Zool. Lilloana 11: 227-333.

- 1959. La fauna de hormigas en el oeste de la Patagonia. Acta Zool. Lilloana. 17: 321-401.

Lavigne, R. J. 1969. Bionomics and nest structure of Pogonomyrmex occidentalis (Hymenoptera: Formicidae). Ann. Entomol. Soc. Am. 62(5): 1166-1175.

Levings, S. C., and J. F. A. Tranielio. 1981. Territoriality, nest dispersion, and community structure in ants. Psyche. 88: 265320.

MacKaY, W. P. 1981. A comparison of the nest phenologies of three species of Pogonomyrmex harvester ants (Hymenoptera: Formicidae). Psyche 88: 25-74.

MöGLICH, M. 1978. Social organization of nest emigration in Leptothorax (Hym., Form.). Insectes Soc. 25 (3); $205-225$.

- AND B. Hölldobler. 1974. Social carrying behavior and division of labor during nest moving in ants. Psyche 81 : 219-236.

Rogers, L. E. 1974. Foraging activity of the western harvester ant in the shortgrass plains ecosystem. Environ. Entomol. 3(3): $420-424$.

VAN Pelt, A. 1976. Nest relocation in the ant Pogonomyrmex barbatus. Ann. Entomol. Soc. Am. 69(3): 493.

WheEleR, W. M. 1910. Ants, their structure, development and behavior. Columbia University Press, New York. 663 pp.

WhrtFord, W. G. 1978. Foraging in seed-harvester ants Pogonomyrmex spp. Ecology 59(1): 185-189.

- P. Johnson, and J. Ramirez. 1976. Comparative ecology of the harvester ants Pogonomyrmex barbatus (F. Smith) and Pogonomyrmex rugosus (Emery). Insectes Soc. 23(2): 117-131. 